\title{
Detecção e Caracterização Molecular Parcial do Grapevine fleck virus em Videiras
}

\author{
Thor V.M. Fajardo', Marcelo Eiras ${ }^{2}$, Paula G. Schenato ${ }^{3 *}$, Osmar Nickel ${ }^{1}$ \& Gilmar B. Kuhn ${ }^{1}$ \\ 'Embrapa Uva e Vinho, Cx. Postal 130, CEP 95700-000, Bento Gonçalves, RS, e-mail: thor@ cnpuv.embrapa.br; ${ }^{2}$ Centro de \\ Sanidade Vegetal, Instituto Biológico de São Paulo, São Paulo, SP; ${ }^{3}$ Universidade de Caxias do Sul - CARVI, Bento \\ Gonçalves, RS
}

(Aceito para publicação em 25/03/2004)

Autor para correspondência: Thor V.M. Fajardo

\section{ABSTRACT}

Detection and partial molecular characterization of Grapevine fleck virus in grapevines

This paper reports the serological detection and partial molecular characterization of Grapevine fleck virus (GFkV) in grapevine (Vitis spp.) samples from the State of Rio Grande do Sul, Brazil. The GFkV was detected mainly in grape indicator cv. Rupestris du Lot showing fleck disease after biological indexing.
A mancha das nervuras é uma virose que apresenta alta incidência e, por ser latente em praticamente todas as cultivares de copa e porta-enxerto de videira (Vitis spp.), faz parte dos programas de seleção sanitária da maioria dos países vitícolas. É causada pelo Grapevine fleck virus (GFkV), família Tymoviridae (Martelli et al., Arch. Virol. 147:1837. 2002), gênero Maculavirus (Martelli et al., Arch. Virol 147:1847. 2002). O GFkV não possui vetor conhecido, não é transmitido mecanicamente, sendo disseminado pelo material propagativo infetado. A cultivar de porta-enxerto Vitis rupestris Scheele cv. Rupestris du Lot é utilizada como indicadora desta virose, apresentando, como sintomas característicos, manchas translúcidas nas folhas, sem formas definidas e que acompanham as nervuras (Kuhn, Fitopatol. Bras. 17:435. 1992). O objetivo deste trabalho foi detectar sorologicamente o GFkV em videiras cv. Rupestris du Lot, mantidas em casa de vegetação na Embrapa Uva e Vinho, exibindo sintomas característicos da doença, e caracterizar parcialmente este isolado viral.

No TAS-ELISA (Boscia et al., Plant Pathology 44: 160.1995) utilizou-se anti-soro comercial contra GFkV (Agritest, Itália). As amostras de folhas novas do porta-enxerto cv. Rupestris du Lot sintomáticas foram trituradas em nitrogênio líquido e tampão Tris- $\mathrm{HCl} 0,5 \mathrm{M}, \mathrm{pH} 8,2, \mathrm{NaCl}$ a 0,8\%, PVP 40000 a $2 \%$, PEG 6000 a $1 \%$ e Tween 20 a 0,05\%. Foram consideradas infetadas as amostras cuja absorbância foi de, no mínimo, duas vezes a verificada nas amostras sadias. O RNA total foi extraído a partir de folhas novas de plantas sintomáticas, utilizando-se o "RNeasy Plant Mini Kit" (Qiagen). Na RT-PCR foram utilizados os oligonucleotídeos FkV1 / FkV2, específicos para GFkV (Sabanadzovic et al., Vitis 35:137. 1996). O fragmento de DNA amplificado foi eluído do gel, ligado ao vetor pGEM-T Easy (Promega), clonado em

*Bolsista da FAPERGS
Escherichia coli DH5 $\alpha$ e seqüenciado (dois clones). As seqüências obtidas de nucleotídeos e aminoácidos deduzidos foram comparadas com outras depositadas no banco de dados GenBank.

Todas as amostras avaliadas por TAS-ELISA reagiram positivamente com o anti-soro contra GFkV. A partir das mesmas amostras amplificou-se um fragmento de DNA de tamanho esperado: $245 \mathrm{bp}$, contendo parte do gene da replicase do GFkV (ORF1), entre os nucleotídeos 5573 e 5817, e em relação ao acesso AJ309022 (Sabanadzovic et al. J. G. Virology 82:2009. 2001). As seqüências obtidas de nucleotídeos e aminoácidos deduzidos (81 aa) (Figura 1) apresentaram maiores correspondências, 93,5\% e $100 \%$, respectivamente, com o isolado italiano MT48 do GFkV (GenBank AJ309022/ CAC84400).

Estes resultados confirmam a presença do GFkV em videiras indexadas positivas, por enxertia em indicadora para a virose da mancha das nervuras. A técnica de RT-PCR juntamente com o ELISA constituem-se em ferramentas úteis para rápida e sensível detecção desse vírus em videiras, especialmente em atividades de monitoramento de campos de plantas-matrizes.

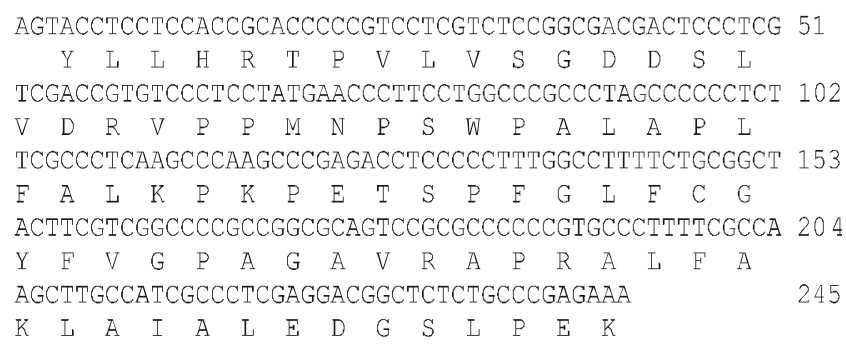

FIG. 1 - Seqüência parcial de nucleotídeos (superior) e aminoácidos deduzidos (inferior) do gene da replicase do Grapevine fleck virus $(\mathrm{GFkV})$. 